\title{
Comparison of hooded and albino rats on the visual cliff'
}

\author{
Denis J. D'Sullivan, LOYOLA UNIVERSITY OF CHICAGO \\ Norman E. Spear, RUTGERS UNIVESITY
}

\begin{abstract}
Fifteen hooded and fifteen albino rats were tested on a visual cliff. The results clearly demonstrated the significantly inferior visual depth perception of the albinos. These results contrast with those of Walk \& Gibson (1961).

\section{Problem}

Several early experimenters (see Munn, 1950) have reported evidence for the apparent superiority of hooded over albino rats in terms of visual acuity and depth perception. Recently, however, Walk and Gibson (1961) have reported no difference between the visualcliff behavior of adult albino and hooded rats. The present experiment was an attempted replication of Walk and Gibson's results.

\section{Subjeets}

The Ss were 15 experimentally naive hooded and 15 naive albino rats, 90-135 days old, which had been bred and raised in the colony at Northwestern University. There were 5 males and 10 females in each group. All Ss were derived from Sprague-Dawley females and any of 3 , genetically-heterozygous, hooded males. Litters produced by this particular combination were half albino and half hooded.

\section{Apparatus}

The basic apparatus was the visual cliff modified after Walk \& Gibson (1961). The entire apparatus was $20 \times 40$ in with $31 / 2$ in sidewall. The depth of the deep side was 12 in while the patterned material was placed flush with the glass on the shallow side. The center board was $20 \times 41 / 2$ in with a 2 -in descent. The entire wooden frame of the apparatus and the center board was painted a flat black while the checker pattern (2-in squares) was red and white. One-sec. timers operated manually in order to measure the various responses. The brightness intensity was measured with a standard Weston light meter. The readings were .9 and .85 for the deep side and the shallow side respectively.

\section{Procedure}

Each $S$ was prehandled for a period of 5 min. per day on each of 3 consecutive days. During this time $\mathrm{S}$ was allowed to roam a large unpainted wooden box and was picked up 5 times. Immediately prior to running each $\mathrm{S}$ was placed in an individual cage for a period of approximately $3 \mathrm{~min}$. following which it was placed on the center board of the visual cliff and tested for a period of $5 \mathrm{~min}$. One-half of the Ss was started from one side of the center board with the other half starting from the other side of the center board. After each $\mathrm{S}$ was run, both sides were sponged with a mild solution of disinfectant.

Three response measures were taken: (1) the initial side chosen, i. e., shallow side or deep side; (2) the entire time spent on the shallow side (not necessarily consecutively); and (3) the number of times $S$ crossed either from the shallow side to the deep side or from the deep side to the shallow side.

\section{Results and Discussion}

The basic results are summarized in Table 1.

A chi-square test on the initial side of descent showed that the hooded rats chose the shallow over the deep side with greater frequency than did the albinos $\left(x^{2}=\right.$ $11.63 ; \mathrm{p}<.01)$. With the $\mathrm{t}$ test, it was found that the albino Ss spent significantly more time on the deep side $(\underline{t}=6.57 ; \mathrm{df}=28 ; \mathrm{p}<.001)$ and made significantly more crossovers $(\underline{t}=3.83 ; \mathrm{df}=28 ; \mathrm{p}<.001)$ than the hooded Ss.

The conclusion from these results is straightforward, though different from that of Walk and Gibson (1961); hooded rats have considerably better visual depth perception than do albinos. Casual observation during testing also supported this conclusion. When a hooded $\mathrm{S}$ crossed over the cliff to the deep side, it exhibited the typical fear reactions, e. g., rigidity of limbs, peaked body, etc., while the albino Ss gave little evidence of such reaction.

Though it is not clear from their report, Walk and Gibson apparently tested their hooded Ss independently

Table 1. Summary of three response measures for hooded and albino rats on the visual cliff.

$\begin{array}{lcc} & \text { Hooded } & \text { Albino } \\ \text { * Initial descent } & & \\ \text { Shallow } & 93 \% & 33 \% \\ \text { Deep } & 7 \% & 67 \% \\ \text { B. Crossovers } & & \\ \text { Mean } & 2.04 & 5.40 \\ \text { S. D. } & 1.67 & 2.90 \\ \text { Time on shallow side } & & \\ \text { Mean } & 232.40 & 93.87 \\ \text { S. D. } & 55.1 & 57.7\end{array}$

*A = the per cent of Ss choosing a particular "depth" of side for initial descent from the center board.

$\mathrm{B}=$ the mean number of times an $\mathrm{S}$ crossed over the center board.

$\mathrm{C}=$ the mean time (in sec.) spent by $\mathrm{S}$ on the shallow side. 
from their albino Ss, and also used less homogeneous Ss (in factors other than pigmentation) than were employed in the present experiment. These points alone, however, would not account for the fact that only 1 of 16 albinos in their study initially chose the deep side compared with 10 of 15 in the present experiment. There is no obvious reason for this contrast in results. It is possible that the difference in size of squares (2 in in the present experiment; $3 / 4$ in in the Walk and Gibson experiment) could have some relevance in terms of texture.

\section{References}

MUNN, N. L. Handbook of psychological research on the rat. Boston: Houghton-Mifflin Co., 1950.

WALK, R. D., \& GIBSON, ELEANOR, J. A comparative and analytical study of visual depth perception. Psychol. Monogr., 1961, 75, 1-44.

\section{Note}

1. This work was partially supported by Grant GB-254 from the National Science Foundation. 